Correspondence to: Professor B K Nicholson

Chemistry Department

University of Waikato

Private Bag 3105

Hamilton

New Zealand

Email: b.nicholson@waikato.ac.nz

Fax: 6478384219

\title{
A manganese carbonyl complex derived from the P,N-bonding ligand (2- aminophenyl)diphenylphosphine.
}

Victor D. Fester, Paul J. Houghton, Lyndsay Main and Brian K Nicholson*

Department of Chemistry, University of Waikato, Private Bag 3105, Hamilton, New

\section{Zealand.}

\section{Synopsis}

The first manganese carbonyl complex derived from (2-aminophenyl)diphenylphosphine is formed on reaction of the ligand with $\left[\mathrm{H}_{3} \mathrm{Mn}_{3}(\mathrm{CO})_{12}\right]$. It contains two bridging amido ligands.

\section{Pictogram}

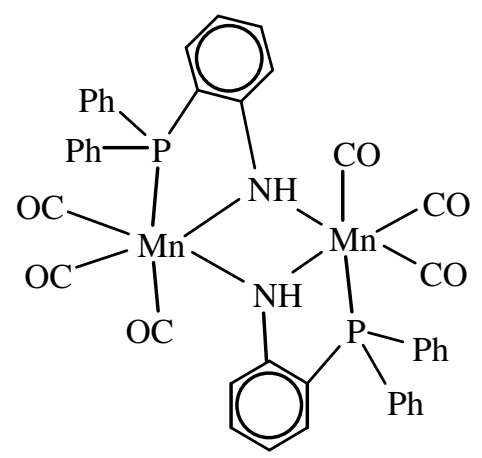




\begin{abstract}
.
Thermal reaction of $\left[\mathrm{H}_{3} \mathrm{Mn}_{3}(\mathrm{CO})_{12}\right]$ with $\mathrm{Ph}_{2} \mathrm{PC}_{6} \mathrm{H}_{4} \mathrm{NH}_{2}-2$ gives good yields of $\left[\mathrm{Mn}_{2}(\mathrm{CO})_{6}\left(\mathrm{PPh}_{2} \mathrm{C}_{6} \mathrm{H}_{4} \mathrm{NH}\right)_{2}\right]$, an X-ray single crystal structure determination of which reveals a $\mathrm{P}, \mathrm{N}$-chelating ligand with each of the $\mathrm{NH}$ groups, formed by deprotonation of the amine groups, bridging the two metal atoms.
\end{abstract}

\title{
1. Introduction.
}

Many bidentate hemilabile ligands have been explored for their ability to combine a stabilising effect on the metal centre with the possibility of readily generating a vacant coordination site for catalysis [1]. The most common ligating atom combinations are $\mathrm{P}, \mathrm{O}$ or $\mathrm{P}, \mathrm{N}$ which exploit the mismatch in bonding tendencies between soft $\mathrm{P}$ and hard $\mathrm{O}$ or N. Recent summaries giving examples are available [2].

One readily prepared ligand which has had some application in organometallic chemistry is $\mathrm{Ph}_{2} \mathrm{PC}_{6} \mathrm{H}_{4} \mathrm{NH}_{2}-2$ (1), which not only includes a soft-hard $\mathrm{P}, \mathrm{N}$ combination but also retains potentially reactive $\mathrm{N}-\mathrm{H}$ bonds [3].

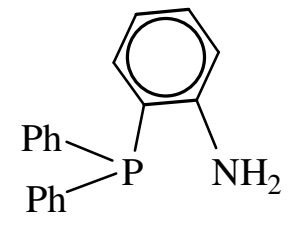

1

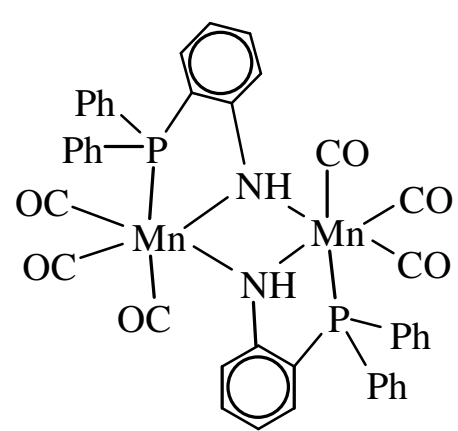


Metal carbonyl complexes derived from 1 have been reported for both mononuclear and cluster compounds [4-6]. However, there are as yet no reports that we are aware of where derivatives of manganese have been prepared with 1. Our longer term interest stems from the possibility of controlling the reactivity of the $\mathrm{Mn}-\mathrm{C}$ bond in cyclomanganated compounds with such ancillary ligands [7], but here we describe a novel complex (2) from initial explorations of the reactions of $\mathbf{1}$ with simpler manganese carbonyls.

\section{Experimental Section}

\subsection{General}

Reactions were carried out under a nitrogen atmosphere using Schlenk techniques and solvents that were distilled under nitrogen from appropriate drying agents before use. Electrospray mass spectra were recorded on a VG Platform II spectrometer, operated as detailed elsewhere [8]. Assignments were confirmed by simulation of the characteristic isotope patterns using the ISOTOPE program [9]. NMR spectra were obtained on a Bruker AC300 instrument operating under standard conditions. IR spectra were recorded on a Digilab Scimitar instrument. $\mathrm{Ph}_{2} \mathrm{PC}_{6} \mathrm{H}_{4} \mathrm{NH}_{2}-2$ and $\left[\mathrm{H}_{3} \mathrm{Mn}_{3}(\mathrm{CO})_{12}\right]$ were prepared by literature methods $[10,11]$.

\subsection{Preparation of 2.}

$\left[\mathrm{H}_{3} \mathrm{Mn}_{3}(\mathrm{CO})_{12}\right](40 \mathrm{mg}, 0.079 \mathrm{mmol})$ was dissolved in heptane $(5 \mathrm{~mL})$ in a Schlenk flask. (2-Aminophenyl)diphenylphosphine $(45 \mathrm{mg}, 0.16 \mathrm{mmol}$ ) was added to the flask and the temperature of the reaction mixture was gradually increased to between 80 and 90 ${ }^{\circ} \mathrm{C}$ over a period of $50 \mathrm{~min}$. During this time a colour change from orange-red to orangeyellow was observed, with a yellow precipitate starting to form at $80^{\circ} \mathrm{C}$. After cooling to 
room temperature, the solvent was removed in vacuo and the residue was redissolved in a small amount of dichloromethane. A similar volume of diethyl ether was added and the mixture was placed in the freezer. After one week, yellow crystals of $\mathbf{2}$ were obtained (40 mg, 61\%). Mp 110-116 ${ }^{\circ} \mathrm{C}$. Found: C 59.99, H 3.62, N 3.38\%; $\mathrm{C}_{42} \mathrm{H}_{30} \mathrm{~N}_{2} \mathrm{O}_{6} \mathrm{P}_{2} \mathrm{Mn}_{2}\left(\mathrm{M}_{\mathrm{r}}=\right.$ 830) requires $\mathrm{C} 60.74, \mathrm{H} 3.65, \mathrm{~N} 3.37 \%$; $v_{\mathrm{CO}}\left(\mathrm{CH}_{2} \mathrm{Cl}_{2}\right) 2002$ (s), 1923(s), 1898(s); ESIMS, $\left(\mathrm{MeOH}\right.$, added NaOMe [8]), positive ion $m / z, 853[\mathrm{M}+\mathrm{Na}]^{+}, 825[\mathrm{M}+\mathrm{Na}-\mathrm{CO}]^{+}$, negative ion $m / z, 801$ [M-H-CO]', 773 [M-H-2CO]. NMR $\left(\mathrm{CDCl}_{3} ; 300 \mathrm{MHz}\right):{ }^{1} \mathrm{H}: \delta 7.0-$ 8.5 (m); the NH signal was either too broad to be observed or was amongst the aryl proton signals and could not be assigned. ${ }^{13} \mathrm{C}$ : Owing to decomposition over the period of accumulation, the spectrum was poor and singlet signals were not resolved; doublet signals assigned to the ring carbons ortho and para to the amino group were at 111.0 (J 7 $\mathrm{Hz})$ and $118.9 \mathrm{ppm}(\mathrm{J} 11 \mathrm{~Hz})$, the remainder overlapping at $128-135 \mathrm{ppm} .{ }^{31} \mathrm{P}: 65.4 \mathrm{ppm}$. $2.3 X$-ray crystallography

X-ray intensity data were collected on a Siemens SMART CCD diffractometer using standard procedures and software. Multiscan absorption corrections were applied (SADABS [12]). Structures were solved by direct methods and developed and refined on $\mathrm{F}^{2}$ using the SHELX programmes [13] operating under WinGX [14]. Hydrogen atoms were included in calculated positions, except for the hydrogen attached to $\mathrm{N}(1)$, which was located as the highest peak in a penultimate difference map and was refined with an isotropic temperature factor.

\subsubsection{Structure of $\left[\mathrm{Mn}_{2}(\mathrm{CO})_{6}\left(\mathrm{Ph}_{2} \mathrm{PC}_{6} \mathrm{H}_{4} \mathrm{NH}\right)_{2}\right] . \mathrm{CH}_{2} \mathrm{Cl}_{2}\left(2 . \mathrm{CH}_{2} \mathrm{Cl}_{2}\right)$.}

Yellow crystals of 2 as the mono-solvate were obtained from $\mathrm{CH}_{2} \mathrm{Cl}_{2}$. 
Crystal data: $\mathrm{C}_{42} \mathrm{H}_{30} \mathrm{~N}_{2} \mathrm{O}_{6} \mathrm{P}_{2} \mathrm{Mn}_{2} \cdot \mathrm{CH}_{2} \mathrm{Cl}_{2}, \mathrm{M}=1000.36$, monoclinic, space group $\mathrm{P} 21 / \mathrm{n}$, a $=10.8871(1), \mathrm{b}=14.7066(1), \mathrm{c}=14.1506(2) \AA, \mathrm{U} 2245.0(1) \AA^{3}, \mathrm{~T} 190 \mathrm{~K}, \mathrm{Z}=2, \mathrm{D}_{\text {calc }}=$ $1.48 \mathrm{~g} \mathrm{~cm}^{-3}, \mu\left(\mathrm{Mo}_{-} \mathrm{K}_{\alpha}\right)=0.921 \mathrm{~mm}^{-1}, \mathrm{~F}(000) 1016 ; 12596$ reflections collected with $2^{\circ}<$ $\theta<26^{\circ}, 4520$ unique $\left(\mathrm{R}_{\mathrm{int}} 0.0433\right)$ used after correction for absorption $\left(\mathrm{T}_{\max , \min } 0.7697\right.$, 0.7329). Crystal dimensions $0.36 \times 0.30 \times 0.30 \mathrm{~mm}^{3}$. Refinement on $\mathrm{F}^{2}$ gave $\mathrm{R}_{1} 0.0563$ [I $>2 \sigma(\mathrm{I})]$ and $w R_{2} 0.1580$ (all data), GoF 1.027. The structure of $\mathbf{2}$ is illustrated in Figure 1, with selected bond parameters summarised in the caption to the Figure.

\section{Results and discussion}

\subsection{Synthesis and properties of 2.}

We were unable to isolate any new compounds from the thermal reaction between the ligand 1 and $\mathrm{Mn}_{2}(\mathrm{CO})_{10}$, decomposition to insoluble brown residues taking place under conditions needed for reaction. However, the trinuclear species $\mathrm{H}_{3} \mathrm{Mn}_{3}(\mathrm{CO})_{12}$ underwent a smooth reaction at $80^{\circ} \mathrm{C}$ with 1 to give good yields of a new species as yellow crystals. These were reasonably air-stable as a solid, but solutions tended to decompose giving a green product. ${ }^{1} \mathrm{H}$ and ${ }^{13} \mathrm{C}$ NMR of 2 gave little useful information, while ${ }^{31} \mathrm{P}$ NMR gave a signal at $\delta 65.4$, well-shifted from that of the free ligand at $\delta$ 19.6. This indicated that a five-membered chelate ring had formed [15], though the shift of 75 ppm is unusually large [16]. The ESI mass spectrum suggested a mass of 830 from an $[\mathrm{M}+\mathrm{Na}]^{+}$ion at $m / z 853$, corresponding to an empirical formula of $\left[\mathrm{Mn}_{2}(\mathrm{CO})_{6}\left(\mathrm{Ph}_{2} \mathrm{PC}_{6} \mathrm{H}_{4} \mathrm{NH}\right)_{2}\right]$. To characterise the complex a single crystal X-ray determination was carried out. The structure is shown in Figure 1. This shows a centrosymmetric molecule consisting of two $\mathrm{Mn}(\mathrm{CO})_{3}$ units each coordinated to a 
phosphorus atom of a mono-deprotonated form of the ligand $\mathbf{1}$. The two halves of the molecule are linked only by the $\mathrm{N}$ atoms from the two ligands; the Mn....Mn distance of $3.267 \AA$ precludes any direct metal-metal bond. The central $\mathrm{Mn}_{2} \mathrm{~N}_{2}$ core of the molecule has strict planarity imposed by the space group symmetry, while the five-membered metallocyclic ring formed by $\mathrm{Mn}(1) \mathrm{P}(1) \mathrm{C}(11) \mathrm{C}(16) \mathrm{N}(1)$ has a slightly folded envelope conformation, with deviations up to $0.18 \AA$ from the least-squares plane. The Mn-N bonds differ slightly with $\mathrm{Mn}(1)-\mathrm{N}(1)$ and $\mathrm{Mn}(1)-\mathrm{N}(1)$ ' being 2.084(3) and 2.150(3) $\AA$ respectively.

Deprotonation of the ligand $\mathbf{1}$ to provide a bridging amido group has been observed before, notably in reactions with $\left[\mathrm{Ru}_{3}(\mathrm{CO})_{12}\right]$ and $\left[\mathrm{Os}_{3}(\mathrm{CO})_{12}\right][5,6]$. However in these cases the clusters remain intact and the amido group bridges a formal $\mathrm{M}-\mathrm{M}$ bond. A doubly bridged $\mathrm{Rh}-\mathrm{Rh}$ bond is also retained in the complex $\left[\mathrm{Rh}_{2} \mathrm{Cl}_{2}(\mathrm{CO})_{2}\left(\mathrm{Ph}_{2} \mathrm{PC}_{6} \mathrm{H}_{4} \mathrm{NH}\right)_{2}\right]$ [17]. Structural characterisation of two metal carbonyl centres linked only by two amido groups appears to be unique to compound $\mathbf{2}$, though a related rhenium example derived from 2-aminopyridine has been spectroscopically established [18].

The route to 2 presumably involves initial replacement of a $\mathrm{CO}$ ligand on $\left[\mathrm{H}_{3} \mathrm{Mn}_{3}(\mathrm{CO})_{12}\right]$ by the $\mathrm{P}$ atom of $\mathbf{1}$. Oxidative addition of an $\mathrm{N}-\mathrm{H}$ bond of the $-\mathrm{NH}_{2}$ group across a metalmetal bond, followed by elimination of $\mathrm{H}_{2}$ would give a species $\mathbf{3}$, which would be related to the known rhenium anion 4 [18]. 


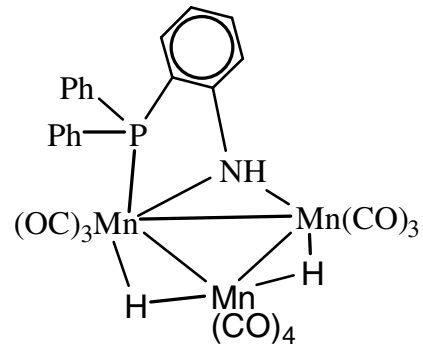

3

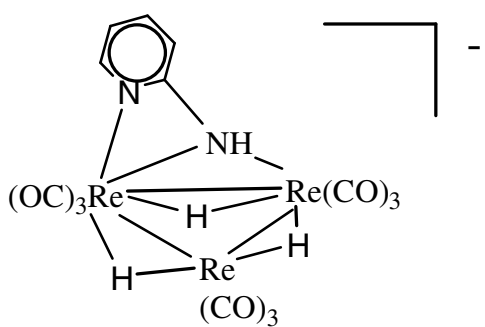

4

Repeating the process with a second ligand molecule apparently leads to fragmentation of the cluster and formation of $\mathbf{2}$.

Other species can be detected in the reaction mixture, for example ESI-MS of the reaction mixture shows additional peaks to those associated with 2 at $\mathrm{m} / z 665$ corresponding to the formula $\left[\mathrm{Mn}(\mathrm{CO})_{2}\left(\mathrm{Ph}_{2} \mathrm{PC}_{6} \mathrm{H}_{4} \mathrm{NH}_{2}\right)_{2}\right]^{+}$, undoubtedly containing two intact bidentate ligand molecules, but we have as yet been unable to isolate this in a pure form for characterisation. This cation would be isoelectronic with the structurally characterised [W(CO)(NO) $\left.\left(\mathrm{Ph}_{2} \mathrm{PC}_{6} \mathrm{H}_{4} \mathrm{NH}_{2}\right)_{2}\right]^{+}[19]$.

\section{Supplementary material.}

Crystallographic data for the structural analyses have been deposited with the Cambridge Crystallographic Data Centre, CCDC no 603564. Copies of this information may be obtained free of charge from the Director, CCDC, 12 Union Rd., Cambridge CB2 1EZ, UK (Fax: +44-1223-336033; e-mail: deposit@ @cdc.cam.ac.uk or http://www.ccdc.cam.ac.uk.

\section{Acknowledgements}


We thank Associate Professor Cliff Rickard, University of Auckland, for collection of Xray intensity data and Ms Kelly Kilpin for assistance with NMR spectroscopy.

\section{References}

1. A. Bader and E. Lindner, Coord. Chem. Rev., 108 (1991) 27; M. Dieguez, O.

Pamies, A. Ruiz, Y. Diaz, S. Castillion, C. Claver, Coord. Chem. Rev., 248

(2004) 2165; P. Laurent, N. L. Bris, H. des Abbayes, Trends Organometal.

Chem., 4 (2002) 131; H. Werner, Dalton Trans., (2003) 3829. C. S. Slone, D. A.

Weinberger, C. A. Mirkin, Prog. Inorg. Chem., 48 (1999) 233.

2. P. Braunstein, Y. Chauvin, J. Nahring, Y. Dusausoy, D. Bayeul, A. Tiripicchio, F. Ugozzoli, J. Chem. Soc., Dalton Trans. (1995) 851; P. Braunstein, F. Naud, Angew. Chem., Int. Ed. Eng., 40 (2001) 680; J. A. Cabeza, Eur. J. Inorg. Chem., (2002) 1559.

3. M. K. Cooper, J. M. Downes, Inorg. Chem., 17 (1978) 880; G. J. Organ, M. K.

Cooper, K. Henrick, M. McPartlin, J. Chem. Soc., Dalton Trans., (1984) 2377.

4. L. Dahlenburg, K. Herbst, H. Berke, J. Organometal. Chem., 585 (1999) 225; J.

Pietsch, L. Dahlenburg, M. Moll, H. Berke, D. Veghini, I. L. Eremenko, J.

Organometal. Chem., 472 (1994) 55; L. Dahlenburg, K. Herbst, G. Liehr, Acta

Cryst., C53 (1997) 1545; L. Dahlenburg, K. Herbst, A. Zahl, J. Organometal.

Chem., 616 (2000) 19; H.-F. Klein, R. Beck, H.-J. Haupt, Eur. J. Inorg. Chem., (2003) 240.

5. C. J. Adams, M. I. Bruce, P. A. Duckworth, P. A. Humphrey, O. Kuhl, E. R. T. Tiekink, W. R. Cullen, P. Braunstein, S. C. Cea, B. W. Skelton, A. H. White, J. 
Organometal. Chem., 467 (1994) 251; C. J. Adams, M. I. Bruce, B. W. Skelton, A. H. White, J. Organometal. Chem., 513 (1996) 255.

6. W. Ainscough, A. M. Brodie, S. L. Ingham, J. M. Waters, J. Organometal. Chem., 468 (1994) 229.

7. $\quad$ L. Main, B. K. Nicholson, Adv. Metal-Org. Chem., 3 (1994) 1.

8. W. Henderson, B. K. Nicholson, L. J. McCaffrey, Polyhedron, 17 (1998) 4291;

W. Henderson, J. S. McIndoe, B. K. Nicholson, P. J. Dyson, J. Chem. Soc., Dalton Trans., (1998) 519.

9. $\quad$ L. J. Arnold, J. Chem. Educ., 69 (1992) 811.

10. M. K. Cooper, J. M. Downes, P. A. Duckworth, Inorg. Synth., 25 (1989) 129.

11. B. F. G. Johnson, R. D. Johnston, J. Lewis, B. H. Robinson, Inorg. Synth., 12 (1970) 44 .

12. R. H. Blessing, Acta Cryst., A51 (1995) 33.

13. G. M. Sheldrick, SHELX97 Programs for the solution and refinement of crystal structures, University of Göttingen, Germany, 1997.

14. L. J. Farrugia, WinGX, Version 1.70.01, University of Glasgow, UK; L. J. Farrugia, J. Appl. Cryst., 32 (1999) 837.

15. P. E. Garrou, Chem. Rev., 81 (1981) 229.

16. M. A. Leeson, B. K. Nicholson, M. R. Olsen, J. Organometal. Chem., 579 (1999) 243.

17. M. K. Cooper, G. J. Organ, P. A. Duckworth, K. Henrick, M. McPartlin, J. Chem. Soc., Dalton Trans., (1988) 2287. 
18. J. A. Cabeza, A. Llamazares, V. Riera, R. Trivedi, Organometallics, 17 (1998) 5580.

19. J. Pietsch, L. Dahlenburg, A. Wolski, H. Berke, I. L. Eremenko, J. Organometal. Chem., 495 (1995) 113. 


\section{Caption to Figure.}

Figure 1. The structure of the centrosymmetric dimer 2 . Bond parameters include bond lengths (̊̊): Mn-P 2.317(1), Mn-N(1) 2.084(3), Mn-N(1)’ 2.150(3), Mn...Mn 3.267(1); bond angles (degrees): Mn-P-C(11) 101.3(2), N(1)-MnN(1)' 79.0(2), Mn-N(1)-Mn' 100.9(2), Mn-N(1)-C(16) 112.1(2). 


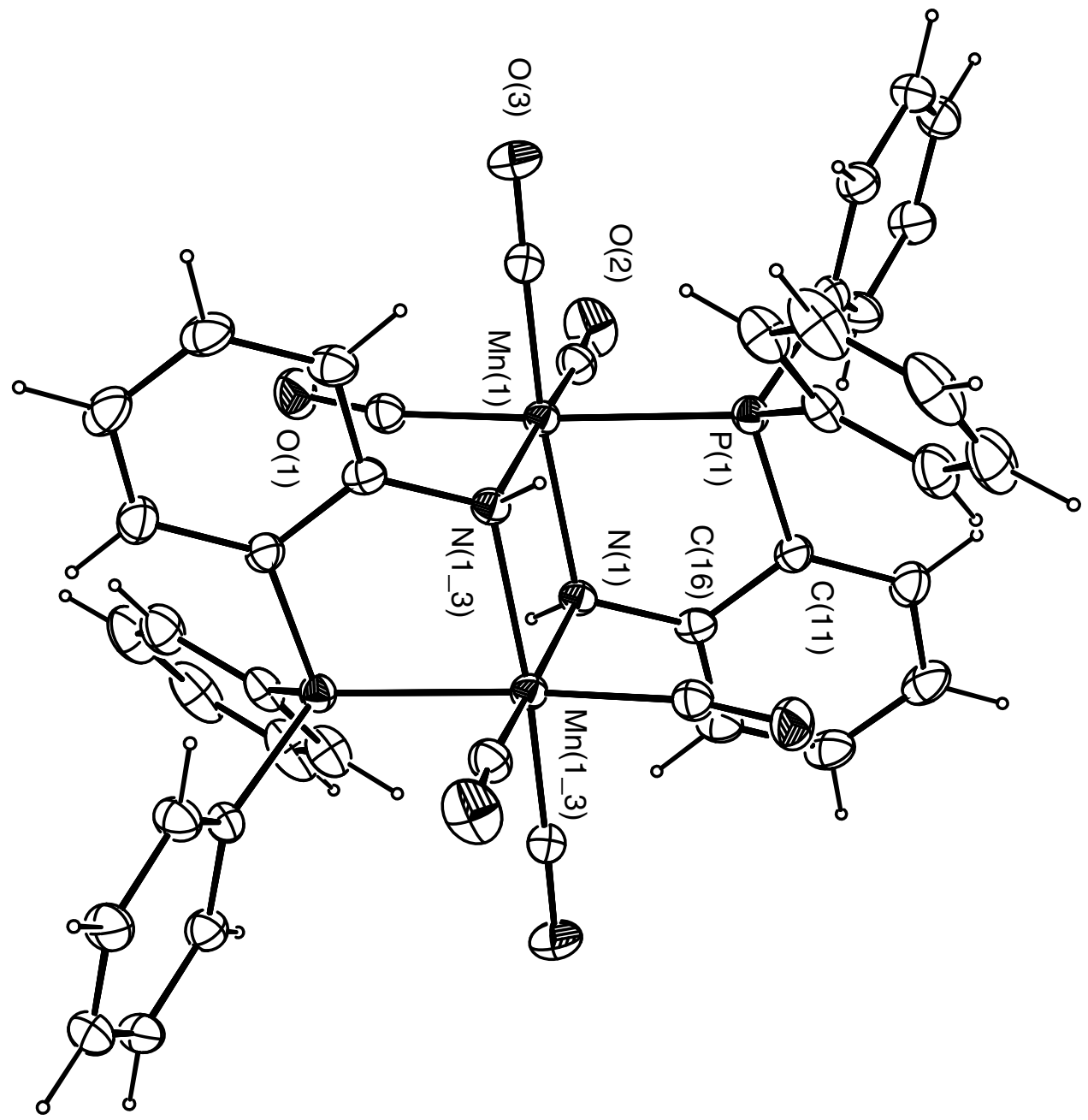

Figure 1 